УДК 811.111: 811. $161.2-115$

https://doi.org/10.31548/philolog2021.01.045

\title{
CORONAVIRUS NEOLOGISMS IN THE ENGLISH AND UKRAINIAN LANGUAGES
}

\author{
M. G. GOLTSOVA, PhD in Philology, Associate Professor, \\ National University of Life and Environmental Sciences of Ukraine \\ E-mail: mariam88@ukr.net \\ https://orcid.org/0000-0003-2385-436X \\ L. V. CHYBIS, M.A., lecturer, \\ Ukrainian Association of Western Australia (Perth, Western Australia) \\ E-mail: larisa201081@ukr.net \\ https://orcid.org/0000-0003-2969-239X
}

\begin{abstract}
The article deals with the coronavirus neologisms in the English and Ukrainian languages which are now becoming widespread. English as a global language reflects the profound effect the outbreak of COVID-19 has had on the lives of people worldwide. Any living language, being a dynamic entity, adapts to changes occurring in the life and culture of its speakers. The coronavirus pandemic has caused the linguistic change and adoption of new phrases as a part of the emergency response to the disaster, such as coronacoma, morona, zoomping, covidient, Blursday etc., across the globe. Some of the words related to the coronovirus outbreak are not strictly neologisms, including the word "neologisms" itself, which dates back to the $19^{\text {th }}$ century. The consequences of the coronavirus outbreak have attracted the attention of numerous scholars throughout the world who have dedicated their research work to the effects of Covid-19 on the language which they highlight from different perspectives. The paper employs a number of general scientific methods, such as the descriptive method, the method of analysis and synthesis, the method of linguistic observation, the method of systematic observation as well as the combination of inductive and deductive methods. The method of contrastive analysis is applied to reveal the unique and similar features of the English and Ukrainian languages. The data were collected from articles, corpora, social media, and different websites. The drivers inducing changes in the vocabulary of a language are identified as a means of helping people to survive the disastrous times. The unprecedented rate of nigh ubiquitous and instantaneous communication via the internet and mobile communication devices at a time of the pandemic has facilitated the exponential growth of neologisms associated with COVID-19. The English and Ukrainian neologisms are coined in different ways preserving their unique means of word formation. Several functions encouraging the appearance and development of coronavirus coinages are analysed in the article.
\end{abstract}

Keywords: neologisms, coronavirus, linguistic change, means of word formation, abbreviations, acronyms, shortening, word coinage.

Introduction. The coronavirus infection has deeply affected all countries around the world. The Covid-19 pandemic highlights and contributes to the linguistic change and adoption of new phrases across the globe. As we can see, the recent Covid-19 outbreak was followed by a wave of neologisms that are now widely used in our everyday lives.

Tony Thorne, a Language Consultant in the Modern Language Centre at King's, says: "Coronaspeak, the new language of the pandemic, can help the public make sense of the unfolding crisis, but it may also increase the levels of stress and confusion if people can't keep up" [9].

The outbreak of COVID-19 led to a whole new specialisation that makes language services a part of the emergency response to disasters. Scientists from all over the world underline the need for linguists to participate in fighting against COVID-19 to prevent and control miscommunication during public emergencies.
In the US and UK the public is taking ownership of the developing 'national conversation' and coming up with its own set of colourful and creative expressions to fill the gaps in the official narrative [9].

We can see the appearance of new creative words and occasional lexical units, such as the pandy (the global pandemic); zoomed out (exhausted after spending too much time in videoconferences); quarantees (promises by governments and companies to people to tide over quarantough times); coronials/coronababies/ короніали/ковідіали (babies born 9 months after COVID-19), be quarantined/to quarantine/ карантинитись (to be in quarantine); covidiots/ковіiісти (people who ignore quarantine and doctor's advice); doomscrolling/думскроліне (the tendency to continue to surf or scroll through bad news, even though that news is saddening, disheartening, or depressing); zoombombing/ зумбомбіне (an unwanted, disruptive intrusion,

(C) M. G. Goltsova, L. V. Chybis

«International journal of philology» | «Міжнародний філологічний часопис» Vol. 12, № 1, 2021 
generally by Internet trolls into a zoom meeting); and карантиносесія (examination taken online during quarantine). In the paper we are going to explore these corona-related neologisms which reflect people's own experiences of life under lockdown in the English and Ukrainian languages.

Recent research and publications. The consequences of the coronavirus outbreak have attracted the attention of scholars from different scientific fields. Coronavirus neologisms have recently become the object of numerous linguistic investigations. Scholars from China (Muhammad Asif, Deng Zhiyong) and Pakistan (Anila Iram, Maria Nisar) in their research Linguistic Analysis of Neologism related to Coronavirus (COVID-19) explore the creation of new words during the outbreak of COVID-19. The theoretical framework of their study is based on three components of neologisms, namely word formation, borrowing, and lexical deviation [2]. Robert Lew and Iztok Kosem discover covid-related neologisms for lexicography. Maryah Khalfan, Huma Batool, Wasima Shehzad explore neologisms related to Covid-19 through the lens of the language-mind relationship, in terms of linguistic relativity [7]. Ukrainian linguists in their research Coronaspeak as Key to Coronaculture: Studying New Cultural Practices Through Neologisms explore neologisms that have entered everyday English discourse during the coronavirus pandemic and formed so-called Coronaspeak [1].

The purpose of this research is to analyse the coronavirus neologisms in the Ukrainian and English languages which are now becoming widespread because of COVID-19.

To reach the objective of the research and to accomplish its tasks, a number of general scientific methods are used. They include the descriptive method, the method of analysis and synthesis, the method of linguistic observation, the method of systematic observation as well as the combination of inductive and deductive methods. The method of contrastive analysis is applied to reveal the unique and similar features of the English and Ukrainian languages.

The COVID-19 pandemic is a global concern which has impacted humanity in many ways, and the interest in the language used in reporting, describing, discussing, metaphorising, and referring to it has motivated the development of language corpora on the pandemic. Two major corpora that are publicly accessible are the Coronavirus Corpus (Mark Davis, 2020) [5] and the Covid-19 corpus (Sketch Engine) [6].

The data were collected from articles, corpora, social media, and different websites and retrieved from January 2020 to November 2020.

Results. Every living language is a dynamic entity. To survive - it needs to adapt to changes occurring in the life and culture of its speakers. Whereas phonological and grammatical structures are relatively stable, vocabulary undergoes alterations easily: new words are constantly introduced, new meanings are invented and some words or their meanings become obsolete and are no longer used. Languages have various triggers encouraging modifications in vocabulary. Pandemics, wars and other events drastically changing people's lives are among the drivers of such changes.

In our article we deal with the neologisms in the English and Ukrainian languages concerning the Coronavirus pandemic. Let us give a definition to the term 'neologism'. Many credible dictionaries, like Collins and Cambridge Dictionaries, define neologism as a new word or expression, or a new meaning for an existing word [10]. The word neologism was a new coinage at the beginning of the $19^{\text {th }}$ century, when it was first borrowed from the French néologisme; though the word itself is of Greek origin: neos (meaning new) and logos (meaning word).

English as a global language reflects the profound effect the outbreak of COVID-19 has had on the lives of people worldwide. The pandemic has introduced a vast spectrum of vocabulary into the life of both native and nonnative English speakers. Many Ukrainian neologisms concerning the pandemic have been borrowed from the English language, like: короніали/coronials, ковіdiворc/covidivorce карантинні челенджі/quarantine challenges and інфодемія/infodemic. At the same time the Ukrainian language has preserved its unique ways of forming words: 1) by means of suffixes (the adjectives короновий, коронавірусний/ некоронавірусний and the adverb коронавірусно); 2) by blending two stems forming compounds (the adjective карантинозалежний and the nouns коронапошесть, коронапереворот); 3) by conversion, for example, some verbs formed from nouns: карантинитись and не сковідитись.

The executive editor of Oxford English Dictionary, Bernadette Parton, stated that it was a rare experience for lexicographers to observe an exponential rise in usage of a single word in a very short period, and for that word to come overwhelmingly to dominate the global discourse. With regard to the unprecedented situation in the world the Dictionary released a special edition out of their regular publications. It was devoted to the changes in the English language vocabulary related to the Coronavirus outbreak, and allocated the following: 19 re-purposed or more prevalent words. Some of them, such as self-isolation, date back to the $19^{\text {th }}$ century. The term was used to refer to self-imposed isolation to keep safe from epidemics. Others, like shelter-in-place was first used in 1976 and meant a safe place during a 
nuclear attack. Nowadays, it is mostly used in the United States and is synonymous to the word lockdown; whereas, confinement, a Victorianera term, is the Franco-European equivalent of the notion lockdown. COVID-19 is a neologism and it is also an abbreviation of coronavirus disease, 2019.

From a linguistic point of view there are several ways by which new words are coined: 1) abbreviations and acronyms (COVID-19 being one of them - $\boldsymbol{C O}$ from corona, $\boldsymbol{V I}$ from virus and $\boldsymbol{D}$ from disease); 2) shortenings (iso for isolation, sanny for sanitiser, pandy for pandemic, quaz meaning to quarantine or rona/рона for coronavirus); 3) compounds (coronapanic/коронапаніка, coronacrisis/коронакриза, corona moaner for the whingers, doomscrolling/думскроліне for 'excessive amount of screen time devoted to reading or watching bad news', coronacuts for 'a haircut done in quarantine', coronacoma/коронакома meaning 'a never ending period of time in lockdown', zoombombing/зумбомбіне meaning 'the intrusion into a video conference'; 4) borrowings from other languages (linguists say German hamsterkauf for 'panic buying' may soon become an English word).

For example, in the $18^{\text {th }}$ century Parisians called the flu that hit Europe la grippe describing its gripping effect on people's throats and chests. Later the word was picked up by the British when the disease headed on to Great Britain and nowadays can be found in many European languages, for example, Ukrainian - epun. Old and new abbreviations have become a part of our modern reality: $\boldsymbol{W} \boldsymbol{F H}$, which stands for 'working from home'; PPE - 'personal protective equipment'; ARDS - 'acute respiratory distress syndrome'; $\boldsymbol{A R \boldsymbol { I }}$ - 'acute respiratory infection'; PUI - 'patient under investigation'; CFR - 'case fatality rate'; $\boldsymbol{B C V}$ - 'before coronavirus", $\boldsymbol{A C V}$ - 'after coronavirus', etc. The acronym WFH appeared in 1995 though back then the term was less familiar, whereas the coinage of PPE ('personal protective equipment') dates back to 1934. Some new coinages may combine in more than one way: isodesk 'a workplace used in confinement', isobaking 'home-baking in confinement', or isobar 'a stocked home bar'.

Several reasons encouraging the appearance and development of Covid-slang or Coronalanguage can be identified. First of all, it is the practical function, which lies in informing the population and describing the course of events, measures taken and possible perspectives. This

\section{References}

1. Alyeksyeyeva, I. O., Chaiuk, T. A., Galitska, E. A. (2020). Coronaspeak as Key to Coronaculture: Studying New Cultural Practices Through Neologisms. International Journal of English Linguistics; Vol. 10, No. 6. p. 202-212. 'language' is often used in a creative humorous key to provide relief for the stressed society and to bring some humour and humility to cope with COVID-19 and quarantines. As Kate Burridge, a professor of linguistics, and Howard Manns, a linguistics lecturer at Monash University, state: "We're leximaniacs at heart and, while the behaviour can occasionally seem dark, we can learn a thing or two by reflecting on those playful coinages that get us through "dicky" times" [4]. In the past, hard times stimulated the creation of playful rhymes. In the 1930s the Great Depression gave rise to ironic reduplications rhyming with geographical names: "ain't no work in Bourke, everything's wrong at Wollongong, things are crook at Tallarook" [4]. Some of the neologisms concerning the Rona have a distinct Australian flavour about them, for example: to magpie meaning 'to grab desirable items in the supermarket'. The critical function deals with negative attribution of other people's behaviour, such as the following neologisms: covidiot/ковідіот/ковігіст/ковід-дисидент (а blend denoting someone who ignores public health advice and behaves selfishly under the circumstances), morona (a person acting foolishly during the pandemic) and some Ukrainian coinages: корона-бандит and коронаабсурд. Finally, the Covid-slang has a socially binding value since it helps to "communicate how serious the situation is, and can foster a spirit of solidarity" as Professor of Lancaster University Elena Semino says [3].

Conclusion. Now it has been a year when the novel virus was first detected in the City of Wuhan in China. The pandemic changed the lives of billions of people throughout the world and a new way of speaking, Covid-slang or Coronalanguage appeared. It has brought an array of new words that we use in daily conversations. Day-to-day speech of ordinary people has become interlaced with highly technical medical terms, which were previously used by a limited group of people, such as scientists and medical professionals. Consequently, nowadays everyone shows a great deal of expertise in the field of medicine irrespective of profession or background, differentiating between the concepts of epidemic and pandemic, quarantine and isolation, respirators and ventilators. The new vocabulary helps people stay safe and informed as well as it offers some relief from the stress during the pandemic.

2. Asif, Muhammad; Zhiyong, Deng; Iram, Anila; Nisar, Maria. Linguistic Analysis of Neologism Related to Coronavirus (COVID-19). Available at SSRN: https://ssrn.com/abstract=3608585 or http://dx.doi.org/10.2139/ssrn.3608585

3. Beyond the battle, far from the frontline: a call 
for alternative ways of talking about Covid-19. Retrieved from: https://www.lancaster.ac.uk/ linguistics/news/beyond-the-battle-far-from-thefrontline-a-call-for-alternative-ways-of-talking-aboutcovid-19

4. Burridge, K., Manns, H. The Conversation. Retrieved from: https://theconversation.com/isoboomer-remover-and-quarantini-how-coronavirus-ischanging-our-language-136729

5. Coronavirus Corpus: https://www.englishcorpora.org/corona/

6. COVID-19 Open Research Dataset (CORD-19). 2020. Version 2020-05-02. Retrieved from https://pages.semanticscholar.org/coronavirusresearch.

7. Khalfan Maryah, Batool Huma, Shehzad Wasima (2020). Covid-19 Neologisms and their
Social Use: An Analysis from the Perspective of Linguistic Relativism. Linguistics and Literature Review (LLR). Volume 6, Issue 2.

8. Kim, H. T., Woods, P., Azman, H., Abdullah, I. H., Hashim, R. S., Rahim, Kosem, I. (2020). COVID-19 Insights and Linguistic Methods. 3L: The Southeast Asian Journal of English Language Studies, 26(2), p. 1-23.

9. King's College of London. (2020). CORONASPEAK - the language of Covid-19 goes viral. Retrieved from https://www.kcl.ac.uk/ news/coronaspeak-the-language-of-covid-19-goesviral

10. Neologism. Cambridge English Dictionary. Retrieved from: https://dictionary.cambridge.org/ dictionary/english/neologism

\section{КОРОНАВІРУСНІ НЕОЛОГІЗМИ \\ В АНГЛІЙСЬКІЙ ТА УКРАЇНСЬКІЙ МОВАХ \\ М. Г. Гольцова, Л. В. Чибіс}

Анотація. У статті розглядаються неологізми англійської та української мов, що пов'язані з темою захворювання на Covid-19. Майже будь-яка важлива подія у світі породжує нові слова та вислови. Короновірусна пандемія також спричинила появу багатьох слів цієї тематики як в українській, так і англійській мовах, наприклад: coronacoma/коронокома, zoomping/зумпінг, covidient/ ковідіент, coronacrisis/коронакриза doomscrolling/думскроліне, coronials/короніали. У науковій праці проаналізовано стан вивчення цієї проблематики в українській та англійській мовознавчих спільнотах. Загальнонаукові методи (опис, індукція, дедукція, інтроспекція) були використані для відбору й аналізу мовного матеріалу та викладу положень дослідження. Метод контрастивного аналізу було використано, щоб виявити спільне та відмінне у способах творення неологізмів української та англійської мов. Матеріалом дослідження слугують неологізми коронавірусної тематики, що добиралися зі статей, корпусів лексики, соціальних мереж. Українські та англійські неологізми утворюються різними способами, зберігаючи свої унікальні способи словотворення.

Ключові слова: неологізм, пандемія, коронавірус, лінгвістична зміна, засоби словотворення, абревіація, акронім, контрастивний аналіз. 